\title{
Board of directors' composition and performance in French CAC 40 listed firms
}

\author{
Ali Ahmadi ${ }^{a *}$ and Abdelfettah Bouri ${ }^{b}$
}

${ }^{a}$ Accounting ph.d. candidate in faculty of economics and management of sfax, airport road km 4, 3018 sfax, bp 1088 Tunisia ${ }^{b}$ Professor in the faculty of economics and management of sfax, airport road $\mathrm{km} \mathrm{4,3018} \mathrm{sfax,} \mathrm{bp} 1088$ Tunisia

\section{H R O N I C L E}

Article history:

Received September 5, 2016

Received in revised format

November 112016

Accepted November 202016

Available online

January 22017

Keywords:

Board composition

CEOs duality

Gender diversity

Firm performance \begin{abstract}
A B S T R A C T
Reflecting investor expectations, most prior corporate governance research attempt to find a relationship between boards of directors' composition and firm financial performance. Specifically, we try to examine the relationship between the boards' size, board independence, CEO duality and gender diversity and two measurements of performance in listed companies in CAC 40, namely return on assets (ROA) and return of equities (ROE). We found evidence provide that board characteristics were positively correlated to the firm' performance. However, our results show a significant association between ROE, ROA and the board of directors' composition. We find significant negative association between financial information and equity-based management compensation. On the other hand, the presence of independent directors on the board seems to affect, positively, the level of financial performance of CAC 40 firms. Likewise, the stewardship theory assumption, the CEO duality is very high and is significantly associated with a higher level of firm performance. The results show that there was a significant relationship between board gender diversity and firm performance from our samples CAC 40 companies. In addition, we find significant negative impact of leverage on the financial performance for CAC 40 firms.
\end{abstract}

\section{Introduction}

The board of directors is one form of internal control mechanisms in corporate since the board members appoint, supervise and remunerate top managers in organizations in addition to strategy formulation (Minguez \& Campbell, 2010; Hasseldine \& Hite, 2003). The subject of women on boards of directors is a growing area of research. Indeed, the presence of women on board was identified by Brennan and McCafferty (1997), more recent study continues in the same path (Luckerath-Rovers \& Wood, 2011; Shehata, 2013) identified the reasons that presence of women on board directors leads to increase firms' values. Firstly, with independent women in the board, and as they are not part of the "old boys" network, thus can increase the firm's value.

\footnotetext{
* Corresponding author

E-mail address: ahmadi2402@gmail.com (A. Ahmadi)

C 2017 Growing Science Ltd. All rights reserved.

doi: 10.5267/j.ac.2017.1.001
} 
Secondly, women member at the board of directors might provide more insights about the firms' opportunities in meeting their customers' needs, since they can better understand customers' needs and behaviours. In a study, Bernardi et al. (2002) supported the idea that board of director with the presence of women would enhance board's monitoring (Carter et al., 2003) and would improve corporate governance, which can lead to ameliorate firms' competitive advantage. The authors summarized the advantages of the presence of women on board of directors as follows: it can improve the diversity of opinions in the boardroom, provide the female role models and mentors bringing strategic input to the board of directors, influence the making decision and leadership styles of the corporate, female's capabilities and availability for director positions and ensuring "better" boardroom behaviour.

Nielsen and Huse (2010) identified that the presence of women on board could contribute to reduce the level of interest conflict and ensure high quality of development activities for board of directors. In a recent study, and to conclude the advantages of gender diversity, Francoeur et al. (2008) provided that the smoother communication and coordination associated with less diverse sets comes to improve the advantages related to the knowledge, quality of decision making, perspective, creativity, and judgment brought forward by heterogeneous groups. Similarly, other study was found that the presence of female gender on board of directors was positively associated with companies' level of profitability (Burke, 1997).

Carter et al. (2003) and Erhardt (2003) found a positive association between the percentage of women on board and firm value. Adams and Ferreira (2009) also supported the view that increasing the percentage of women on board would enhance the board's successfulness as they would raise issues at board meetings that would not have been raised in homogenous boards. The positive correlation is more pronounced in, first, sectors where women form a larger share of the labour force (such as the services sector) and, second, where complementarities in skills and critical thinking are in high demand (such as high-tech and knowledge-intensive sectors).

Francoeur et al. (2008) reported a positive relationship between the proportion of women in senior management levels and abnormal returns in complex environments but no significant relationship concerning women on board was reported. Nielsen and Huse (2010) also reported a positive relationship between women on the board and the board's strategic control. Carter et al. (2010) found no significant association between gender type and firm performance. Finally, Gul et al. (2011) argued the existence of a positive association between gender diversity and the level of stock price informativeness. The association between the presence of female gender on board of directors and corporate disclosure can be explained by the agency theory and the stakeholder theory. For the agency theory, it has been criticised with respect to the relationship between board diversity and firm value by Francoeur et al. (2008). Indeed the authors provide that from an agency-theoretic standpoint, when one considers the overall impact of gender diversity on various duties being assumed by a board of directors, it is thus impossible to tell, whether promoting greater female participation will enhance or impair corporate governance and, as a direct consequence, firm financial performance.

Also, they supported using the stakeholder theory rather than the agency theory and they argued also that there are many studies have confirmed the accuracy of stakeholder theory. In a similarly study, Carter et al. (2003) was used the agency theory to explain the association between presence of women on board and firm value. Gul et al. (2011) provided that the gender diversity in the boards of directors improve the quality of disclosure through better monitoring. Based on the agency theory, since presence of women on board increases board independence as discussed earlier, therefore, a positive relationship between the presence of women on board and corporate disclosure is expected. Accordingly, both of the agency theory and the stakeholder theory predict a positive association between presence of women on board and corporate disclosure. 
The remainder of this paper is structured as follows. A Literature review and research hypotheses are presented next, followed by a description of the data and variables measurement. We then present the regression models and results, followed by concluding remarks.

\section{Literature review and research hypotheses}

There are several studies on whether or not the board size has an impact on the firm performance. Indeed, Coles et al. (2008) argue that any company with larger boards is more likely to improve the level of financial performance. In contrast, Guest (2009) reports an inverse relationship linked the board size of directors and firm performance. Similar result provided by Reddy et al. (2008) for New Zealand listed-firms. Furthermore, the median board size for New Zealand companies is six directors which is less than what Jensen and Meckling (1976) suggest for companies in the U.S. However, the board of directors with small size in New Zealand firms fits with its small market criteria. Though the result is inconclusive, it is assumed that larger boards provide more expertise, greater management oversight and access to a wider range of resources; therefore to balance the skills required in the board room, New Zealand companies may require larger boards.

\section{H1: board size and firm performance are positively correlated.}

An independent director may improve the management hierarchy with the identities of the 3rd party. For the potential investor who invests, the firm' value would elevate if outside directors were employed. With independent directors, investors will think that the financial and nonfinancial aspects of the firm are better than other without outside board member. Ertimura et al. (2010) reported that firm with independent directors would yield better performance. Indeed, the independent directors are able to supervise and to control the operations through the implementation of their supervision authority. Also, Chau and Gray (2010) provided that the performance of company with independent directors would be better than a company without independent directors. So this research establishes hypothesis 2 according to the literatures described above.

Hypothesis 2: the level of independent director in board of directors and financial performance of company are negatively correlated.

The stewardship theory offers a complementary perception states that the stakeholders are good stewards to firms' resources and can contribute in the improvement of her efficiency (Donaldson \& Davis 1991). Gillan (2006) provided a positive relationship between CEO duality and firm financial performance. Similarly, Faleye (2007) found that CEO duality was positively correlated to organizational complexity, the CEO reputation and the level of managerial ownership. These findings are similarly with those of Adams et al. (2005) and Jackling and Johl (2009) were argued that the shareholders' benefits are enhanced by combination of chairman and CEO function. The stewardship theory yields that the CEO duality can be found in more consistent strategies' formulation and implementation; and subsequently better firm performance. The theory voices a view of a positive managerial attitude and motivation such as a sense of achievement, altruism or responsibility, and may offer an alternative to agency theory explanation regarding a positive relationship between CEO duality and firm performance (Donaldson et al., 1991). Therefore, under the stewardship framework, it is hypothesized that:

\section{$H$ 3: duality of function of CEOs and Chairman of the Board and firm performance are positively correlated.}

Gender diversity studies have evolved into a challenging study issue in academia for the last years. Most of these studies have commenced from the fact that there are an enhancement numbers of women in top management as well as on the boards of directors. Most of the studies in the area of the effect of gender diversity of the board were focused on profitability and, so far, there is no consensus in the literature on the association between female presence and corporate performance. Several researches 
provide that gender diversity leads to increase corporate performance while others argue there is not such relationship (Carter, at al., 2003; Gregory-Smith, et al., 2014).

Associated to the above is idea from prior literature on the existence of differences between men and women, risk taking, decision-making, communication and firm performance (Rose, 2007). Gender diversity literature emphasizes that diversity may enhance the board's decision making process as new perceptions on various issues are presented and combined with a mutual exchange of ideas between members of the board with dispersed backgrounds and experience (Alvarez \& McCaffery, 2000). Watson et al. (1993) argued that the gender diversity leads to increase the creativity and innovation, knowledge, and therefore becoming a competitive advantage.

The findings provided by Huse and Solberg (2006) reveal that the women on board decision making processes starts from the point that decision-making does not only take place within the boardroom but also before, during and after meetings as well as outside the meetings. This can be indicated that women are more prepared than men for meetings and are therefore they will be more likely to make the best decisions. Schubert et al. (2006) argued that the women have better multi-tasking skills, methods of risk management and communication abilities as compared to their male counterparts. These abilities make women more competent and willing to take on different responsibilities at the same time as well making them better at communication and management of different situations within and outside the firm. The findings provided by these two studies are similar than the argument raised by Burke (1997): "increasing women's board presence enriches board information, perspectives, debate and decision making”.

In addition to improving the effectiveness of corporate governance, literature indicates that gender diversity also improves firm performance. A vast amount of literatures has examined the relationship between gender diversity and performance (Carter et al., 2003; Rose, 2007; Erhardt et al., 2003). Whilst the literature on gender diversity continues to grow, the empirical study on board gender diversity and corporate performance remains mixed and largely concentrated. Carter et al. (2003) examined the association between board composition and firm value for Fortune 1000 firms and provided that there was a significant and positive relationship associate the fraction of women or minorities on the board to the firm value.

The authors found that firms making a commitment to enhance the number of women on board also to have more minorities on their boards of directors and vice versa. Similarly, the studies by Erhardt et al. (2003) report a positive relationship between the gender diversity and firm performance when they investigated the relationship between board composition diversity and the level of financial performance for large US firms and the relationship of board gender diversity to organizational performance, respectively.

Inversely, Rose (2007) found no significant relationship between director's gender diversity and financial performance. Indeed, Watson (2002) in a study based on the argument that female entrepreneurs are more likely to maximize the firm size thresholds (smaller than those of their male counterparts) beyond which they would not prefer to expand hypothesized that female controlled businesses would generate lower outputs compared with male controlled business.

Carter et al. (2003) provided a positive association between board diversity and firm value amongst Fortune 1000 firms measured by Tobin's Q. Similarly, Julizaerma and Sori (2012) provided a positive relationship linked the presence of female gender on the board of directors to the firm performance in Malaysian companies. Conversely, Wang and Clift (2009) argued that board gender diversity would not significantly improve accounting measures of financial performance measured by the return on equity (ROE) and the return on assets (ROA). Adams and Ferreira (2009) reported a negative relationship between gender diversity on the board of directors and firm performance, the authors 
suggested that board of directors with female gender may lead to over monitoring for companies that already have strong governance in place. We posit our hypothesis:

\section{H4. Board gender diversity and firm's financial performance are positively correlated.}

\section{Data and variables measurement}

\section{DATA}

The data for this study is based on CAC 40 companies. Following prior research like Owusu-Ansah (1998) and Akhtaruddin (2005), this study is limited to non-financial companies and therefore are ignored four financial institution refers to their different disclosing requirements in question. The sample period includes the data from 2011 to 2013. The remaining 108 firms representing a significant proportion $(92.5 \%)$ of the total population of French firms listed on the CAC 40 respectively comprise the final sample for this study. The sample composed by firm is distributed as follows: $22.2 \%$ belongs to the manufacturing sector and the technology sector, followed by firms engaged in health activities (11.1\%). No other general business sector yielded more than $10 \%$ of the sample (Basic materials, the construction and building materials, Gas oil firms represent $8.3 \%$; the trade activities $5.6 \%$ while firms pertaining to other tertiary/service business represent $14 \%$ of the sample). Our study seeks to explore the publicly available information, to achieve this, a web-based search was performed during the fourth quarter of 2014, locating the corporate websites of the sample firms was identified.

\section{Table 1}

CAC 40: French companies components our samples distributed by industry

\begin{tabular}{lcc}
\hline Industry & Code & $\begin{array}{c}\text { Number of firms in the sample per } \\
\text { country and industry }\end{array}$ \\
\hline \hline Basic materials (BM) & 1 & 3 \\
Healthcare (Health) & 2 & 4 \\
Manufacturing (Manf) & 3 & 8 \\
Technology (Tech) & 4 & 8 \\
Trade (Trad) & 5 & 2 \\
Construction and building materials (CBM) & 6 & 3 \\
Other services (OS) & 7 & 8 \\
\hline Total & 7 & 36 \\
\hline
\end{tabular}

\section{Variables measurement}

Our study uses two financial attributes measures; namely return on equity (ROE) and return on assets (ROA). The OLS regression analysis includes both board composition characteristics and firm characteristics.

According to the agency theory the characteristics of the board can affect the quality and firm financial performance. Several recent theoretical and empirical studies examined this issue such as the studies of Clarkson et al., (2003), Barako et al. (2006) and Cheung (2010). These features concern:

- The size of the Board;

- The presence of independent directors;

- Duality of functions of Chief Executive Officer and Chairman of the Board;

- The gender diversity.

Board Size of directors was measured using the total number of directors in the board (Jackling \& Johl, 2009). The measure of the presence of independent directors is the number of independent directors 
divided by total board size (Anderson \& Reeb, 2003). Director in the board titles containing the terms "independent", "non-executive" or "outside" are categorized as independent directors and nonindependent for otherwise. Adams and Ferreira (2009) found that the relationship between board size, board independence and gender diversity can be largely mechanical and difficult to interpret.

Mak and Li (2001) argued that when a single individual wears the hats of both the CEO and chairman of the board, that provides the managerial dominance is greatly enhanced since that individual is more aligned with management than with stockholders. The duality of functions of Chief Executive Officer and Chairman of the Board is a dummy variable that takes a value of 1 in the presence duality of functions and zero for otherwise (Hanifa \& Cook, 2002; Gul \& Leung, 2004).

Gender diversity measure: calculated by the average proportion of female directors on the boards of the sample firms during the research period (2011-2013). The use of a multi-period average measure allows better control of changes in board diversity, can increase the reliability and also makes the analysis more dynamic (Erhardt et al., 2003; Ryan \& Haslam, 2005). In addition to the gender test variable, the study further controls for the effects of firm characteristic that have been found in prior research to have an influence on the financial performance. One departure from most of the earlier research on the board gender diversity is the inclusion of a control variable for prior performance, as per Erhardt et al. (2003). There are many arguments for adopting this method. Firstly, as provided by Erhardt et al. (2003), measuring the financial performance at two different points in time better controls for the market fluctuations and gives more consistent results. Secondly, an implantation of a control for prior financial performance reflects that the model' regression captures changes in firm performance from a prior year, and this can mitigate several biases that may arise due to country-level differences such as the variation in the accounting standards and rules. Finally, the effect of gender diversity on financial performance occurs over time, and the effect of strategic decision making on firm performance requires many years to materialize (Carter et al., 2010; Chung \& Trivedi, 2003).

Under this operationalization of different variables and in order to examine the multiple association between firm' financial performance and boards composition of CAC 40 firms, the generic mathematical equation of our analysis upon which an econometric model would be utilized for its verification, has the following form:

$$
\begin{aligned}
& \text { PERFORM }_{\mathrm{it}}=\beta_{0}+\beta_{1} \text { BSIZE }_{i t}+\beta_{2} I N D E P_{i t}+\beta_{3} D U A L_{i t}+\beta_{4} G N D R_{i t}+\beta_{5} G E A R_{i t}+ \\
& \beta_{6} L O G C P_{i t}+\beta_{7} I_{N D U S T_{i t}}+e_{i t}
\end{aligned}
$$

where; $\quad$ PERFORM $_{\text {it }}=\left\{\mathrm{ROE}_{\mathrm{it}}, \mathrm{ROA}_{\mathrm{it}}\right\}$

Table 2

\begin{tabular}{|c|c|c|}
\hline Variables & Label & Definition and computation \\
\hline Return on equity & ROE & $\begin{array}{l}\text { The return on equity equal to income before extraordinary items scaled by total } \\
\text { equities at the end of the year. }\end{array}$ \\
\hline Return on assets & ROA & $\begin{array}{l}\text { The return on assets equal to income before extraordinary items scaled by total } \\
\text { assets at the end of the year. }\end{array}$ \\
\hline Board size & BSIZE & Number of directors \\
\hline Board independence & BINDP & Percentage of independent directors \\
\hline Duality & DUAL & Equal to 1 if one individual serves as both chairman and CEO and 0 for otherwise. \\
\hline Gender diversity & GNDR & Percentage of female directors \\
\hline Leverage ratio & GEAR & The total debt scaled by total assets at the end of the year. \\
\hline Firm size. & LOGCP & Is the natural logarithm of total assets at the end of the year? \\
\hline
\end{tabular}

Summarises the dependent and explanatory variables used in this study and their measurement 


\section{The regression models and results}

Panel A in the Table 3 presents the descriptive statistics for the dependent variable full sample used in the empirical model. From the descriptive statistics we observe that on mean the firm performance, respectively for the study' measurement (ROE, ROA), takes values of $19,81 \%$, and $4,70495 \%$, respectively. The level of financial performance measured by ROE ranges from $2,5 \%$ to $31,29 \%$, whilst, the value takes by the second measurement ranges from $-5,9 \%$ to $10 \%$. Panel B of Table 3 summarizes the segmentation of the level of financial performance based on the proportion of female in the board of directors of CAC 40 firms. The table presents a significant difference between firms' financial performance that have no female directors and others with female gender in the board directors. Indeed, the group of firms with gender diversity presents a high level of financial performance such as measured by ROE and ROA in mean and median values than other firms without gender diversity. The result reveals significant differences in board characteristics between the sample countries. As shown in Panel B of Table 3, significant differences exist between firms that have female directors and those that do not. Most notably, firms with, at least, one female director outperform firms that do not have any female directors by a mean of $1.76 \%$ in ROA and $1 \%$ in ROE. These findings are consistent with previous studies, e.g. Mijntje (2011), where the results show that firms with women directors perform better than those without women on their boards.

Overall, the board of directors is characterised by a mean of size equal to 10.81 with a mean proportion of independent directors of $48 \%$ and $59 \%$ of combination between function of CEOs and Chairman of the Board. The mean leverage (GEAR) is high and amounts to $44.55 \%$ of total assets. The mean of firm size $(\log c p)$ is 7.01 .

\section{Table 3}

Descriptive statistics

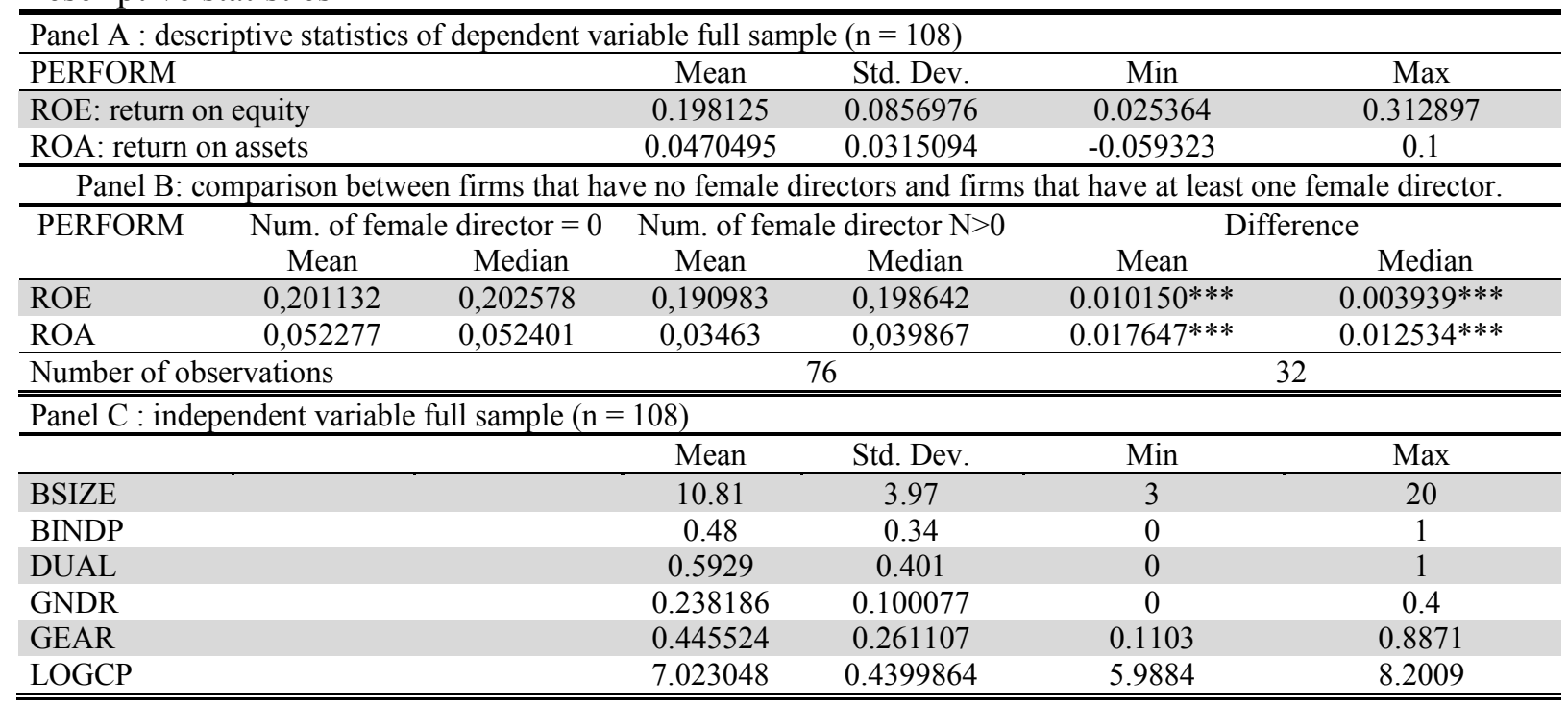

Table 4 shows the result of regression. The findings found support for H1 (board size). Consistent with Saleh et al. (2005), it can be said that the board size is positively correlated to the ROE measurement of firm financial performance. Consequently, it generates positive influence on the managers to mitigate the conflict of interest and personal interest and thus, able to ensure that the managers are strive to work for the betterment of firm performance. Whilst, it affects none significantly the firm performance such measured by ROA. This was initially supported earlier, where BSIZE has a positive and significant relationship with firm performance and is consistent with Saleh et al. (2005). The findings support ( $H 1)$ and provides evidence that larger board size tends to ensure that the management control of the company is strong. 
The board independence ( $\mathrm{H} 2)$ has a significant positive relationship with firm performance and subsequently support the expected hypotheses for the two measurements of the firm performance, i.e. ROE and ROA. The finding provides evidence that those companies having more outside directors able to enhance firm value because there is no personal interest being exercised. The finding is contrast with Johari et al. (2008) and Saat et al. (2011) that reports a positive impact on performance due to more independent directors refer to the agency problem, think objectively since they do not hold executive position in firm and able to buy in external expertise which will yield company performance.

Also, the findings show a significant and positive relationship between firm performance with the duality and subsequently support the expected hypotheses (H 3). The above results are supported by prior researches on the relationship between leadership structure and firm performance. This is in contrast with the result of other studies conducted by Leng (2004) and Yasser (2011) where they reported that duality leadership structure does not any effect on the firm performance. Also, Ho and Wong (2001) asserted that Firms with the combination of chairman and chief executive officer/managing director (CEO duality) are considered to be more managerially dominated.

The literature argues that gender diversity in the board of directors adds value by improving board monitoring, providing board of directors' capital and legitimacy, bringing more perspectives to the table, enhancing the collaboration and mentoring of managers and improving the relationships with stakeholders. The results, presented in Table 4, indicate a positive association between board gender diversity and ROE (Model 1) and ROA (Model 2). These significant results may be because of gender diversity and support the expected hypotheses. In similar vein, using data on Spanish Board of Directors composition, Campbell and Minguez-Vera (2010) provided that the percentage of women in the Board has a positive impact on Tobin's Q value. Adams and Ferreira (2009) also reported the positive effect of female directors on firm's outcomes.

Dobbin and Jung (2011) analyzed whether the effect of the presence of female directors in the Board affects the company's profit and stock performance, their idea was motivated by the fact that women have been holding an increasing number of Board seats in U.S firms. The authors provided that firms with high number of women in the Board of Directors would not experience any increase or decrease in performance. On the other hand, the change in the number of female Board members appears to be significant for institutional investors. Smith el al. (2005) stated the advantages that can be generated by the presence of gender diversity in board, where the women directors may better understand particular market conditions than men, which may bring more creativity and quality to board decision making. Indeed, higher gender diversity on the board may generate a better public image of the firm and enhance firm performance. In addition, it is possible that the involvement of gender diversity in board explores external talent pool. Furthermore, the number of female top managers may positively influence the career development of women in lower positions by motivate them as inspiring model.

Table 4

Regression

\begin{tabular}{lcccl}
\hline & & Model 1 & & Model 2 \\
\hline BSIZE & $(1.214)$ & $0.017^{* *}$ & $(0.539)$ & 0.125 \\
BINDP & $(0.982)$ & $0.082^{* * *}$ & $(1.127)$ & $0.01^{*}$ \\
DUAL & $(1.366)$ & $0.047^{* *}$ & $(0.754)$ & $0.095^{* * *}$ \\
GNDR & $(1.002)$ & $0.009^{*}$ & $(1.002)$ & $0.087^{* * *}$ \\
GEAR & $(-0.986)$ & 0.235 & $(-3.312)$ & $0.044^{* *}$ \\
LOGCP & $(2.713)$ & $0.012^{* *}$ & $(0.162)$ & .198 \\
\hline \hline R-Squared & .458 & & .427 & .396 \\
Adj R-Squared & .417 & & 6.114 & \\
F( 6, 101) & 8.995 & & 0.000 \\
Prob $>$ F & 0.000 & &
\end{tabular}




\section{Conclusion}

Previous research suggests that company performance was significantly associated with board of directors' composition. The purpose of the study specifically was to investigate the relationship between the boards' size, board independence, CEO duality and gender diversity and tow measurement of performance in listed companies in CAC 40 for the period of 2011-2013. The theoretical and empirical literature on corporate governance offers two alternative perspectives about the CEO duality; the agency theory advocates that the separation of the two roles is an important determinant to a board's independence and effectiveness. In contrast, the stewardship theory postulates that firms with a unified leadership structure operate more efficiently through better coordination and unambiguous command, thus deal more effectively with strategic challenges. The leadership structure of CAC 40 companies is mostly characterized by the separation of roles of CEO and chairman.

The current study has both theoretical and practical implications. First and foremost, it takes to consideration on the interactions between the board composition and firms characteristics when we study their effects on firm performance. Second, the empirical results show that firm financial performance increases with board independence, duality leadership structure and gender diversity firm size, and decreases with leverage level among French listed firms during the study period. The paper established how firm performance measuring shed light on the impact of board of directors' composition, firm size and leverage. The findings of the study reveal that most out of the relationship expected are supported with a high level of significance.

The suggestion in previous literature that French companies had a greater concern with financial matters was reinforced in the sample studied in this research. Investigating the factors of board's effectiveness with multiple theoretical studies may help develop more effective corporate governance models. In view that our study is the first step in many regards, its limitations should be noted for example, this study is based on CAC 40 firms. However, a large sample and more recent data would provide more reliable results.

\section{Acknowledgement}

The authors would like to thank the anonymous referees for constructive comments on earlier version of this paper.

\section{References}

Adams, R. B., Almeida, H., \& Ferreira, D. (2005). Powerful CEOs and their impact on corporate performance. Review of Financial Studies, 18(4), 1403-1432.

Adams, R. B., \& Ferreira, D. (2009). Women in the boardroom and their impact on governance and performance. Journal of Financial Economics, 94(2), 291-309.

Akhtaruddin, M. (2005). Corporate mandatory disclosure practices in Bangladesh. The International Journal of Accounting, 40(4), 399-422.

Alvarez, R.M., \& McCaffery, E.J. (2000). Gender and Tax, Gender and American Politics: Women, Men, and the Political Process, J. Josephson and S. Tolleson-Rinehard (eds), M.E. Sharpe, New York, pp. 91-113.

Anderson, R. C., \& Reeb, D. M. (2003). Founding-family ownership and firm performance: evidence from the S\&P 500. The Journal of Finance, 58(3), 1301-1328.

Barako, D. G., Hancock, P., \& Izan, H. Y. (2006). Factors influencing voluntary corporate disclosure by Kenyan companies. Corporate Governance: An International Review, 14(2), 107-125. 
Bernardi, R. A., Bean, D. F., \& Weippert, K. M. (2002). Signaling gender diversity through annual report pictures: A research note on image management. Accounting, Auditing \& Accountability Journal, 15(4), 609-616.

Brennan, N., \& McCafferty, J. (1997). Corporate Governance Practices in Irish companies. Irish Business and Administrative Research, 18, 116-135

Burke, R. J. (1997). Women on corporate boards of directors: A needed resource. In Women in Corporate Management (pp. 37-43). Springer Netherlands.

Campbell, K., \& Vera, A. M. (2010). Female board appointments and firm valuation: Short and longterm effects. Journal of Management \& Governance, 14(1), 37-59.

Carter, D. A., D'Souza, F., Simkins, B. J., \& Simpson, W. G. (2010). The gender and ethnic diversity of US boards and board committees and firm financial performance. Corporate Governance: An International Review, 18(5), 396-414.

Carter, D. A., Simkins, B. J., \& Simpson, W. G. (2003). Corporate governance, board diversity, and firm value. Financial Review, 38(1), 33-53.

Chau, G., \& Gray, S. J. (2010). Family ownership, board independence and voluntary disclosure: Evidence from Hong Kong. Journal of International Accounting, Auditing and Taxation, 19(2), 93109.

Chung, J., \& Trivedi, V. U. (2003). The effect of friendly persuasion and gender on tax comliance behavior. Journal of Business Ethics, 47(2), 133-145.

Cheung, Y. L., Jiang, P., \& Tan, W. (2010). A transparency disclosure index measuring disclosures: Chinese listed companies. Journal of Accounting and Public Policy, 29(3), 259-280.

Cheung, Y. L., Jiang, P., \& Tan, W. (2010). A transparency disclosure index measuring disclosures: Chinese listed companies. Journal of Accounting and Public Policy, 29(3), 259-280.

Coles, J. L., Daniel, N. D., \& Naveen, L. (2008). Boards: Does one size fit all?. Journal of Financial Economics, 87(2), 329-356.

Donaldson, L., \& Davis, J. H. (1991). Stewardship theory or agency theory: CEO governance and shareholder returns. Australian Journal of Management, 16(1), 49-64.

Erhardt, N. L., Werbel, J. D., \& Shrader, C. B. (2003). Board of director diversity and firm financial performance. Corporate governance: An International Review, 11(2), 102-111.

Ertimur, Y., Ferri, F., \& Stubben, S. R. (2010). Board of directors' responsiveness to shareholders: Evidence from shareholder proposals. Journal of Corporate Finance, 16(1), 53-72.

Dobbin, F., \& Jung, J. (2011). Corporate board gender diversity and stock performance: The competence gap or institutional investor bias?". North Carolina Law Review 89(3), 809-838.

Faleye, O. (2007). Classified boards, firm value, and managerial entrenchment. Journal of Financial Economics, 83(2), 501-529.

Fehr-Duda, H., De Gennaro, M., \& Schubert, R. (2006). Gender, financial risk, and probability weights. Theory and Decision, 60(2-3), 283-313.

Francoeur, C., Labelle, R., \& Sinclair-Desgagné, B. (2008). Gender diversity in corporate governance and top management. Journal of Business Ethics, 81(1), 83-95.

Gillan, S. L. (2006). Recent developments in corporate governance: An overview. Journal of Corporate Finance, 12(3), 381-402.

Gregory-Smith, I., Main, B. G., \& O'Reilly, C. A. (2014). Appointments, pay and performance in UK boardrooms by gender. The Economic Journal, 124(574), F109-F128.

Guest, P. M. (2008). The determinants of board size and composition: Evidence from the UK. Journal of Corporate Finance, 14(1), 51-72.

Gul, F. A., \& Leung, S. (2004). Board leadership, outside directors' expertise and voluntary corporate disclosures. Journal of Accounting and Public Policy, 23(5), 351-379.

Gul, F. A., Srinidhi, B., \& Ng, A. C. (2011). Does board gender diversity improve the informativeness of stock prices?. Journal of Accounting and Economics, 51(3), 314-338.

Haniffa, R. M., \& Cooke, T. E. (2002). Culture, corporate governance and disclosure in Malaysian corporations. Abacus, 38(3), 317-349. 
Hasseldine, J., \& Hite, P. A. (2003). Framing, gender and tax compliance. Journal of Economic Psychology, 24(4), 517-533.

Ho, S. S., \& Wong, K. S. (2001). A study of corporate disclosure practice and effectiveness in Hong Kong. Journal of International Financial Management \& Accounting, 12(1), 75-102.

Huse, M., \& Grethe Solberg, A. (2006). Gender-related boardroom dynamics: How Scandinavian women make and can make contributions on corporate boards. Women in Management Review, 21(2), 113-130.

Jackling, B., \& Johl, S. (2009). Board structure and firm performance: Evidence from India's top companies. Corporate Governance: An International Review, 17(4), 492-509.

Jensen, M. C., \& Meckling, W. H. (1976). Theory of the firm: Managerial behavior, agency costs and ownership structure. Journal of Financial Economics, 3(4), 305-360.

Johari, N. H., Saleh, N. M., Jaffar, R., \& Hassan, M. S. (2009). The influence of board independence, competency and ownership on earnings management in Malaysia. International Journal of Economics and Management, 2(2), 281-306.

Julizaerma, M. K., \& Sori, Z. M. (2012). Gender diversity in the boardroom and firm performance of Malaysian public listed companies. Procedia-Social and Behavioral Sciences, 65, 1077-1085.

Chang Aik Leng, A. (2004). The Impact of Corporate Governance Practices on Firms' Financial Performance. ASEAN Economic Bulletin, 21(3), 308-18.

Luckerath-Rovers, M., and Woods, A. de. (2011). Code de conduite pour les administrateurs non exécutifs et des superviseurs. Journal of Business Ethics, 100(3), 465-481.

Mak, Y. T., \& Li, Y. (2001). Determinants of corporate ownership and board structure: evidence from Singapore. Journal of Corporate Finance, 7(3), 235-256.

Lückerath-Rovers, M. (2013). Women on boards and firm performance. Journal of Management \& Governance, 17(2), 491-509.

Saat, N. A. M., Karbhari, Y., Heravi, S., \& Nassir, A. M. (2011). Effective Oversight Roles of Board of Directors-The Case of Listed Firms on Bursa Malaysia. World review of business research, 1(1), 231-245.

Nielsen, S., \& Huse, M. (2010). Women directors' contribution to board decision-making and strategic involvement: The role of equality perception. European Management Review, 7(1), 16-29.

Owusu-Ansah, S. (1998). The impact of corporate attribites on the extent of mandatory disclosure and reporting by listed companies in Zimbabwe. The International Journal of Accounting, 33(5), 605631.

Reddy, K., Locke, S., Scrimgeour, F., \& Gunasekarage, A. (2008). Corporate governance practices of small cap companies and their financial performance: an empirical study in New Zealand. International Journal of Business Governance and Ethics, 4(1), 51-78.

Rose, C. (2007). Does female board representation influence firm performance? The Danish evidence. Corporate Governance: An International Review, 15(2), 404-413.

Ryan, M. K., \& Haslam, S. A. (2005). The glass cliff: Evidence that women are over-represented in precarious leadership positions. British Journal of Management, 16(2), 81-90.

Saleh, N. M., Iskandar, T. M., \& Rahmat, M. M. (2005). Earnings management and board characteristics: Evidence from Malaysia. Jurnal Pengurusan, 24(4), 77-103.

Shehata, N. F. (2013). How could board diversity influence corporate disclosure. Corporate Board: Role, Duties \& Composition, 9(3), 42-49.

Smith, N., Smith, V., \& Verner, M. (2006). Do women in top management affect firm performance? A panel study of 2,500 Danish firms. International Journal of Productivity and Performance Management, 55(7), 569-593.

Watson, J. (2002). Comparing the performance of male-and female-controlled businesses: relating outputs to inputs. Entrepreneurship: Theory and Practice, 26(3), 91-101.

Yasser, Q. R. (2011). Corporate governance and performance: An Analysis of Pakistani listed firms. Global Journal of Management and Business Research, 11(10), 81-90. 


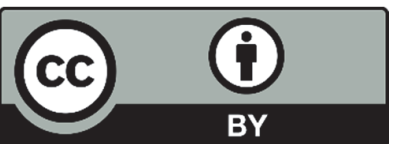

(C) 2017 by the authors; licensee Growing Science, Canada. This is an open access article distributed under the terms and conditions of the Creative Commons Attribution (CC-BY) license (http://creativecommons.org/licenses/by/4.0/). 